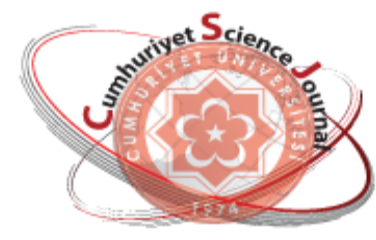

e-ISSN: 2587-246X

ISSN: 2587-2680

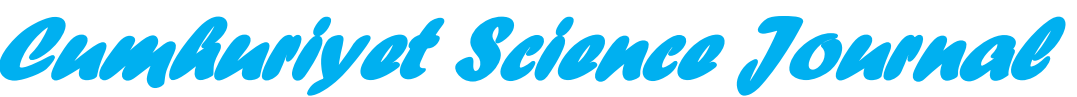

CST

Cumhuriyet Sci. J., Vol.38-3 (2017) 516-524

\title{
Association Between Anti-Proliferative Activity of Evernia Prunastri with the Cellular Apoptotic Pathway
}

\author{
Onder YUMRUTAS ${ }^{1 *}$, Celal GUVEN ${ }^{2}$, Yusuf OZAY ${ }^{1}$, Isil ALBENIZ ${ }^{3}$, Mufide AYDOGAN \\ AHBAB ${ }^{4}$, Ibrahim BOZGEYIK ${ }^{1}$, Atilla YILDIZ ${ }^{5}$, Haydar BAGIS ${ }^{6}$, Leyla TURKER SENER ${ }^{3}$ \\ ${ }^{1}$ Department of Medical Biology, Faculty of Medicine, Adlyaman University, Adiyaman, TURKEY, \\ ${ }^{2}$ Department of Biophysics, Faculty of Medicine, Niğde Ömer Halisdemir University, Niğde, TURKEY, \\ ${ }^{3}$ Department of Biophysics, Faculty of Medicine, Istanbul University, Istanbul, TURKEY, \\ ${ }^{4}$ Department of Biology, Faculty of Science, Hacettepe University, Ankara, TURKEY, \\ ${ }^{5}$ Department of Biology, Faculty of Science, Ankara University, Ankara, TURKEY, \\ ${ }^{6}$ Department of Medical Genetics, Faculty of Medicine, Adiyaman University, Adiyaman, TURKEY
}

\begin{abstract}
Evernia prunastri (L.) Ach, belonging to Parmeliaceae, is an important lichen species in Turkey. Previous studies was reported that $E$. prunastri have significant antioxidant, antimicrobial and anticancer compounds in its structure. Although antiproliferative effects of E. prunastri are determined in some types of cancer, there is little information about the pathway of this activity. Accordingly, we aimed to determine the association between anti-proliferative activities of E. prunastri extracts with the cellular apoptotic pathway. Determination of cell viability was assessed by MTT assay. The xCELLigence system was used to monitor cell proliferation. To reveal induction apoptosis, expression of apoptotic pathway proteins, F-actin staining, ANNEXIN V/propodium iodide (PI) staining was used. As a result, E. prunastri $\mathrm{MeOH}$ extracts were found to have anti-proliferative activities especially in high doses ( $<<0.05$ for 1,5 and $25 \mu \mathrm{g} \mathrm{ml}^{-1} ; \mathrm{p}<0.01$ for $125 \mu \mathrm{g}$ $\mathrm{ml}^{-1}$ ). Also, the extracts were found to be not inducing apoptosis in flow cytometric measurements. In addition, there was no significant decrease or increase in protein expressions of apoptotic pathway proteins. Lastly, density of actin filaments was not affected. $\mathrm{MeOH}$ extract of E. prunastri was found to have antiproliferative activities, yet these anti-proliferative activities were not related to cellular apoptotic pathways.
\end{abstract}

Keywords: Breast cancer, Cytotoxicity, Apoptosis, F-actine, Evernia prunastri.

\section{Evernia Prunastri’nin Antiproliferatif Aktivitesi ve Hücresel Apoptotik Yolak Arasindaki İlişki}

Özet: Parmeliaceae'ye ait olan Evernia prunastri (L.) Ach, Türkiye yetişen önemli bir liken türüdür. önceki çalışmalarda E. Prunastri'nin yapısında bulanan kimyasallardan dolayı antioksidan, antimikrobiyal ve antikanser aktivitelere sahip oldukları belirtilmiştir. E. Prunastri’nin bazı kanser hücre tiplerinde antiproliferatif aktiviteleri bilinmekle birlikte bu aktivitenin yolağı hakkında bilgilerimiz oldukça sınırlıdır. Bundan dolayı, çalışmamızda E. Prunastri ekstraktının antiproliferatif etkileri ve hücresel apoptotik yolak arasında ilişkinin belirlenmesi amaçlanmıştır. Bu amaç için, meme kanseri hücrelerini E. Prunastri ekstraktlarına maruz bırakılmış ve hücre canlılığı MTT boyama ve xCELLigence system ile belirlenmiştir. Annexine V/PI boyama ile Apoptozun indüksiyonu, westernblot ile apoptotik proteinlerin ekspresyonu ve

\footnotetext{
* Corresponding author. Email address: yumrutasonder@gmail.com

http://dergipark.gov.tr/csj $\quad$ (C) 2016 Faculty of Science, Cumhuriyet University
} 
floresan boyama ile aktin flamentlerinin hücresel yoğunluğu belirlenmiştir. E. Prunastri MeOH ekstraktının

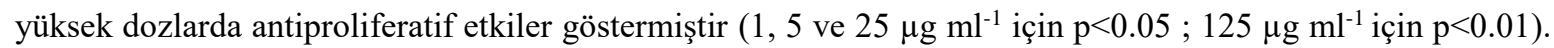
Ancak ekstrakt uygulaması sonrasında apoptozun indüklenmediği ve apoptotik protein seviyelerinin değişmediği belirlenmiştir. Ayrıca F-aktin seviyesininde değişmediği gözlemlenmiştir. Sonuç olarak, E. Prunastri $\mathrm{MeOH}$ ekstraktının meme kanseri hücreleri üzerine antiproliferatif bir etkiye sahip olduğu ancak bu etkinin apoptotik yolakla ilişkili olmadığı düşünülmektedir.

Anahtar Kelimeler: Meme kanseri, Sitotoksisite, Apoptoz, F-aktin, Evernia prunastri.

\section{INTRODUCTION}

Breast cancer is a deadly major health problem predominantly affects female population and has one of the highest rates of mortality among other types of cancer [1]. Many women are diagnosed with breast cancer each year. It is estimated that approximately 232.000 invasive and 60.000 in sutu people were diagnosed with breast cancer by 2015 in United States [2]. In chemoprevention of breast cancer, usually selective estrogen receptor modulators and aromatase inhibitors are used. However, these drugs have important levels of side effects [2]. Therefore, there is a need for novel anti-cancer agents to target breast cancer. Especially, plant-derived compounds bear strong anti-cancer activities and therefore screening these compounds is very important. Bak et al. [3] reported that many of phytochemicals exhibit the anticancer activity in breast cancer. Also, there are many compounds that are not defined for breast cancer treatment. Lichens are found widely around the world [4] and have been used for medical purposes for many years [5]. It is known that lichens produce naturally active compounds in their structures [6] and so, lichens are used in the fields of medicine, pharmacology, food and perfumery due to the naturally bioactive compounds in their structure [6]. Moreover, the data about their anticancer activities is limited in literature. The anticancer activity of compounds obtained from lichens showed on melanoma [7], breast cancer/ protolichesterinic acid [8], prostate cancer/protolichesterinic acid and vicanicin [9], colorectal and ovarian cancer/usnic and atronorin [10]. However, many lichen species have been studied for their biological activities, only a few of compounds have been purified and identified, their anticancer potentials have not yet been fully illuminated.

E. prunastri, belonging to Parmeliaceae, is an important lichen species in Turkey. In previous studies, it was reported that E. prunastri have significant antioxidant, antimicrobial and anticancer compounds in its structure $[11,12]$. The total phenolic content of $E$. prunastri methanol extracts was determined to be $80.73 \mathrm{mg} \mathrm{GA} \mathrm{g}^{-1}$ and the total flavonoid content was $27.46 \mathrm{mg} \mathrm{Ru}$ $\mathrm{g}^{-1}$ [12]. In addition, Kosanic et al [11] determined evernic acid, atranorin, chloroatranorin, physodic acid and usnic acid in E. prunastri acetone extracts. Although the antiproliferative effects of E. prunastri have been determined in some types of cancer, there is little information about the pathway of this activity. Accordingly, in the present study, we aimed to determine the association between anti-proliferative activity of E. prunastri extracts with the cellular apoptotic pathways.

\section{MATERIALS and METHODS}

\subsection{Preparation of Extracts}

In the preparation of extracts, E. prunastri samples were air-dried and standard Soxhlet extraction method were followed. Briefly, mushroom materials $(2 \mathrm{~g})$ were air-dried and then the samples was extracted in a Soxhlet apparatus with $\mathrm{MeOH}(250 \mathrm{ml})$ at $60{ }^{\circ} \mathrm{C}$. Extract was then concentrated by using a rotary vacuum evaporator. Finaly, the extracts were kept in the dark at $+4{ }^{\circ} \mathrm{C}$ until further experiments. 


\subsection{Cell Culture}

MCF7 breast cancer cells were purchased from ATCC (American Type Culture Collection, VA, USA). For the cultivation of cells, Dulbecco's modified eagle's medium (DMEM) (SigmaAldrich, MO, USA) were used. Mediums were supplemented with $10 \%$ fetal calf serum (FCS) (Sigma-Aldrich, MO, USA). For appropriate culturing conditions cells were preserved in air, 95\%; carbon dioxide (CO2), 5\% conditions at $37^{\circ} \mathrm{C}$.

\subsection{Determination of cell viability by MTT assay}

MTT (3- [4,5- dimethylthiazol- 2- yl]- 2,5diphenyl- tetrazolium bromide) were used to measure cell viability of MCF-7 cells. Briefly, cells were detached using $3.0 \mathrm{~mL}$ of TrypsinEDTA solution (Sigma-Aldrich, MO, USA) after reaching 70-80\% confluency and seeded to 96well plates and incubated for 24 hours. After 24 hours, varying dilutions of $(1,5,25$ and $125 \mu \mathrm{g}$ $\mathrm{ml}^{-1}$ ) extracts were applied and cells were incubated for 48 hours. Control cells were only treated with the growth medium not supplemented with FCS. After 48 hours of incubation, the supernatants were replaced with $1 \mathrm{mg} \mathrm{ml}^{-1}$ MTT (Sigma) dissolved in growth medium and incubated at $37^{\circ} \mathrm{C}$ until purple precipitate is visible. Following incubation, supernatants were removed and MTT absorbed by cells were dissolved adding dimethyl sulfoxide (DMSO) (Sigma-Aldrich, MO, USA). Plates were read at $570 \mathrm{~nm}$ using an Epoch spectrophotometer (BioTek Instruments, Winooska, VT).

\subsection{Dynamic monitoring of cell proliferation using the $\mathrm{xCELLigence} \mathrm{system}$}

Real-Time monitoring of cell viability was achieved using quantitative measurement of the cell proliferation in xCELLigence system. MCF7 cells seeded in an E-plate 16 (ACEA Bioscience Inc.) at a density of 100,000, 50,000, 25,000, $12,500,6,250,3,125$ and 1,562 cells/well and cell indexes were recorded for a period of $24 \mathrm{~h}$.
2.5. Determination of Apoptotic and Antiapoptotic Proteins by Western Blot Analysis

For the western blot analysis, total cell fractions were mixed with sample loading reagent and subjected to denaturation for 5 minutes. Proteins were resolved on $12 \%$ polyacrylamide gel and transferred to nitrocellulose membranes (Bio-Rad Laboratories, Inc.). For immunoblotting, membranes were incubated with the blocking buffer and treated with primary and alkaline phosphatase conjugated secondary antibodies. Signal generation was achieved by using NBT/BCIP substrate solution. Following antibodies were used in the western blotting experiments; anti-Cytochrome $\mathrm{C}$, anti-active Caspase-3, anti-p53, anti-Bcl-2 primary antibodies (all from Abcam, Inc., Cambridge, MA).

\subsection{Determination of Actin Filaments by Immunofluorescence Method}

Cells cultured on coverslips were subjected to various concentrations of $E$. prunastri extract and subjected to F-actin staining. Fluorescentlylabeled phalloidin (Alexa Fluor ${ }^{\circledR} 595$ phalloidin, Thermo Fisher Scientific) was used to visualize and quantitate actin filaments in MCF-7 breast cancer cells. For the nuclear counterstain, DAPI (Thermo Fisher Scientific) was used.

\subsection{Apoptosis Assays by Flow Cytometry}

For the cell cycle analysis, cells were seeded at a $1 \times 10^{5} / \mathrm{ml}$ density to 6 -well plates and effective dose of E. prunastri extract were applied for a period of 24 and 48 hours. After extract treatment cells were trypsinized and subjected to propidium iodide staining (PI) and analyzed at Beckman coulter flow cytometer. For the apoptosis analysis, cells were seeded at a $1 \times 10^{6} / \mathrm{ml}$ density to 6 -well plates and effective dose of $E$. prunastri extract was applied for a period of 24 and 48 hours. PE Annexin V Apoptosis Detection Kit I (Becton Dickinson, Pharmingen, UK) was used to analyze induction of apoptosis in cells. Analysis was carried out using Beckman coulter flow cytometer. 


\subsection{Statistical analysis}

Statistical analysis of data was achieved using GraphPad Prism (v6.02) and SPSS (version 20) software. For all statistics $\mathrm{p}$ values were twotailed, and $\mathrm{p}<0.05$ were accepted as statistically significant.

\section{RESULTS}

\subsection{The Anti-proliferative Effects of $E$. prunastri on MCF7 Breast Cancer Cells}

Different doses of $1,5,25,125 \mu \mathrm{g} \mathrm{ml}^{-1}$ extract were delivered to MCF7 cells for a period of 24 hours. Anti-proliferative activity of extracts was determined by using MTT and xCELLigence Real-Time methods. As a result, the numbers of MCF7 cells were found to be decreased in especially in $125 \mu \mathrm{g} / \mathrm{ml}$ dose and the effect was observed in a dose-dependent manner (Figure 1). Additionally, in 1, 5 and $25 \mu \mathrm{g} \mathrm{ml}^{-1}$ doses similar anti-proliferative effects were observed. In parallel to MTT results, in xCELLigence RealTime cell viability monitoring system similar activities was observed. Highest anti-proliferative activity was observed in 25 and $125 \mu \mathrm{g} \mathrm{ml}^{-1}$ doses as compared to control group.
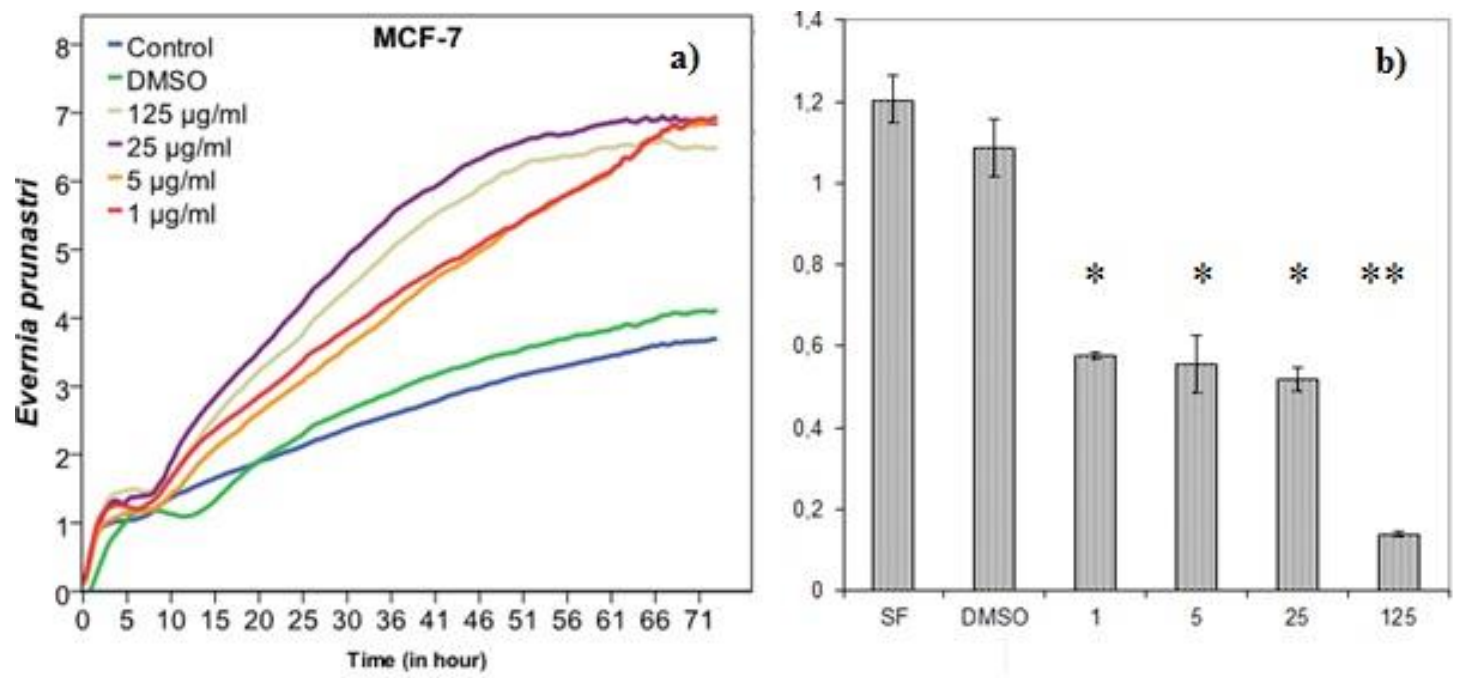

Figure 1. Cell viability of MCF-7 cells treated with E. prunastri by using a typical MTT assay. a:xCELLigence Real-Time cell viability monitoring system and $b$ : MTT test results.

\subsection{Determination of Apoptosis by Using FACS}

Standard doses $\left(1,5,25\right.$ and $\left.125 \mu \mathrm{g} \mathrm{ml}^{-1}\right)$ used in the MTT assay were also used in the apoptosis induction experiment. Cells were treated with the extracts for a period of 24 hours. As observed in Figure 2, no apoptotic activity was observed after 24 hours of extract treatments. In a small portion of cells, a necrotic cell death was observed. Extract treatments were prolonged to 48 hours and no change observed in the apoptotic activity. 


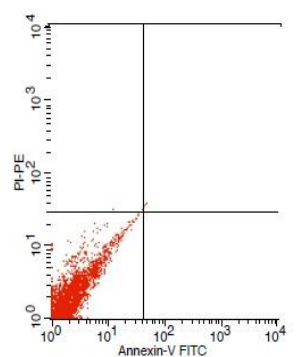

a)

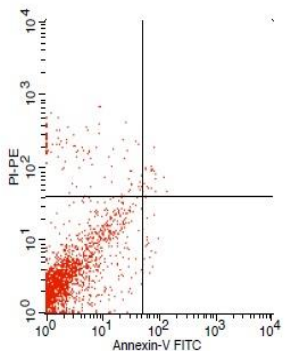

f)

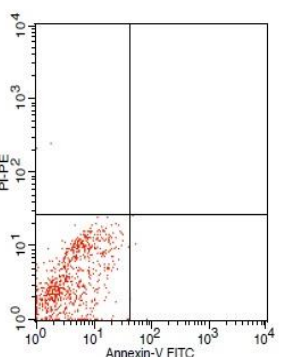

b)

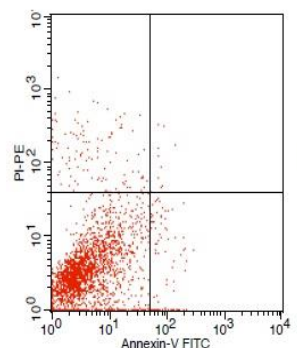

g)

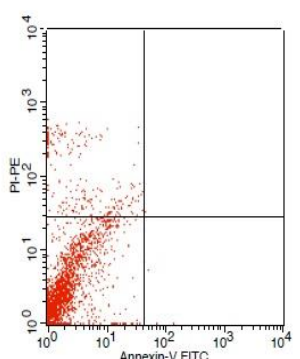

c)

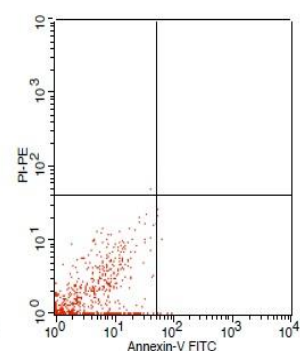

h)

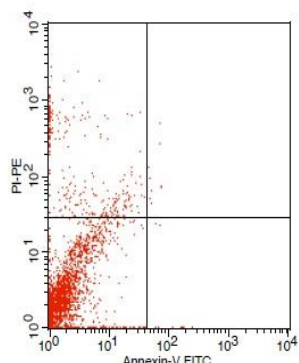

d)

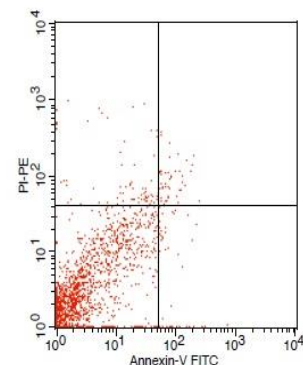

i)

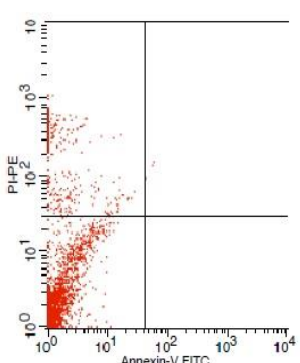

e)

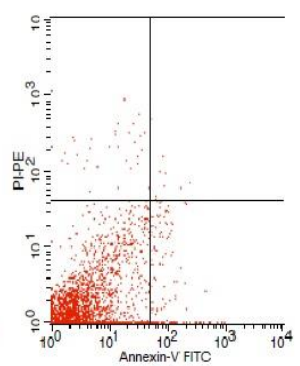

j)

Figure 2. Flow cytometric analysis of Annexin V/PI staining. MCF-7 was treated with 0,0 (DMSO) (negative control), 1, 5, 25 and $125 \mu \mathrm{g} \mathrm{ml}^{-1}$ E. prunastri extracts for 4 hours to induce apoptosis. Cells were stained with Annexin V/PI according to the Annexin V Apoptosis Detection staining protocol.

\subsection{Determination of Apoptotic Proteins by Immunoblotting}

To determine how proteins in the apoptotic pathway effected as a result of E. prunastri extract treatments, we also determined the protein expression of some apoptotic marker proteins by using immunoblotting. For the immunoblotting, lowest and highest doses of extracts were applied to MCF7 cells for a period of 24 hours and expression levels of p53, Casp 3 (Caspase 3) and Bcl-2 were determined (Figure 3). As a result, p53 protein levels were observed to be reduced after extract treatments as compared to control. In addition, while low dose extract treatments were found to be increased Casp3 and Bcl2 protein levels, in high dose extract treatment this effect disappeared. But, these increase and reduction in level of the protein were insignificant statistically ( $p>0.05$ ).
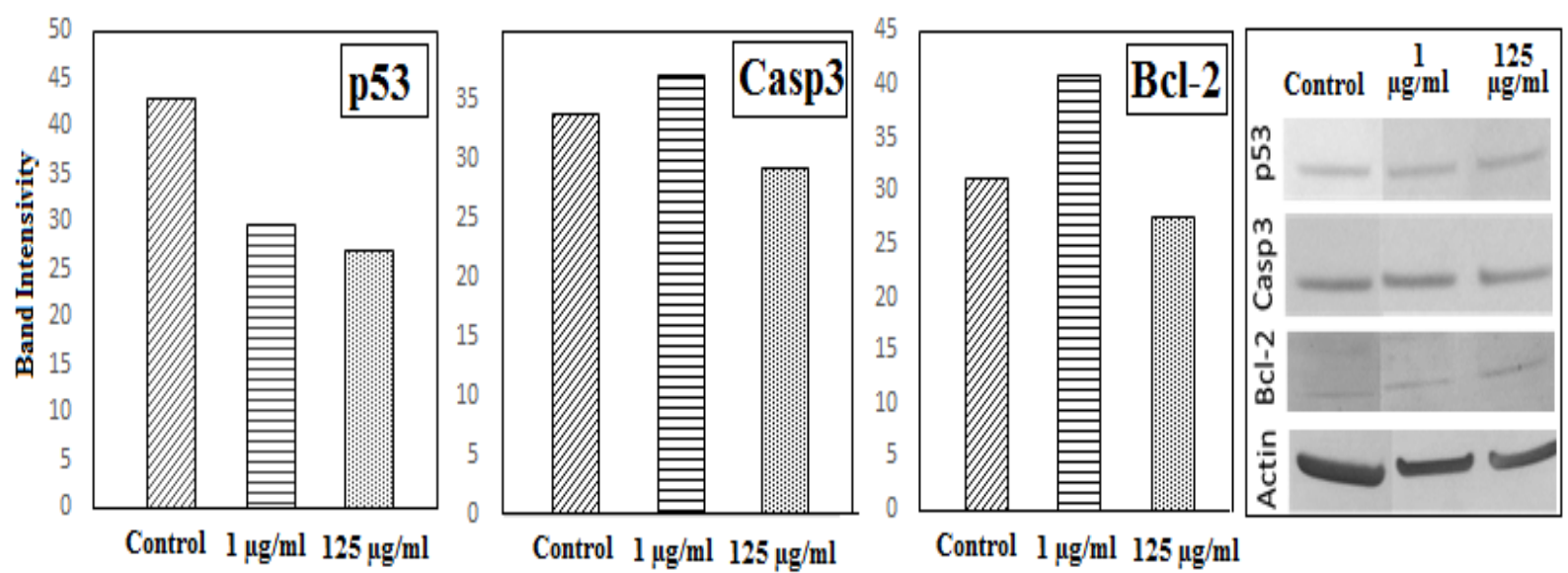

Figure 3. Levels of apoptotic and antiapoptotic proteins in MCF7 cells after treatment of MeOH extract of E. Prunastri. 


\subsection{Immunofluorescence Imaging of Actin Filaments}

As we all know degradation of the cytoskeleton is one of the indicators of the apoptosis. Similar to immunoblotting experiments, lowest and highest doses of extracts were applied to cells. A slight decrease in actin filament density was observed only in $125 \mu \mathrm{g} \mathrm{m}{ }^{-1}$ extract treated cells as presented in Figure 4.

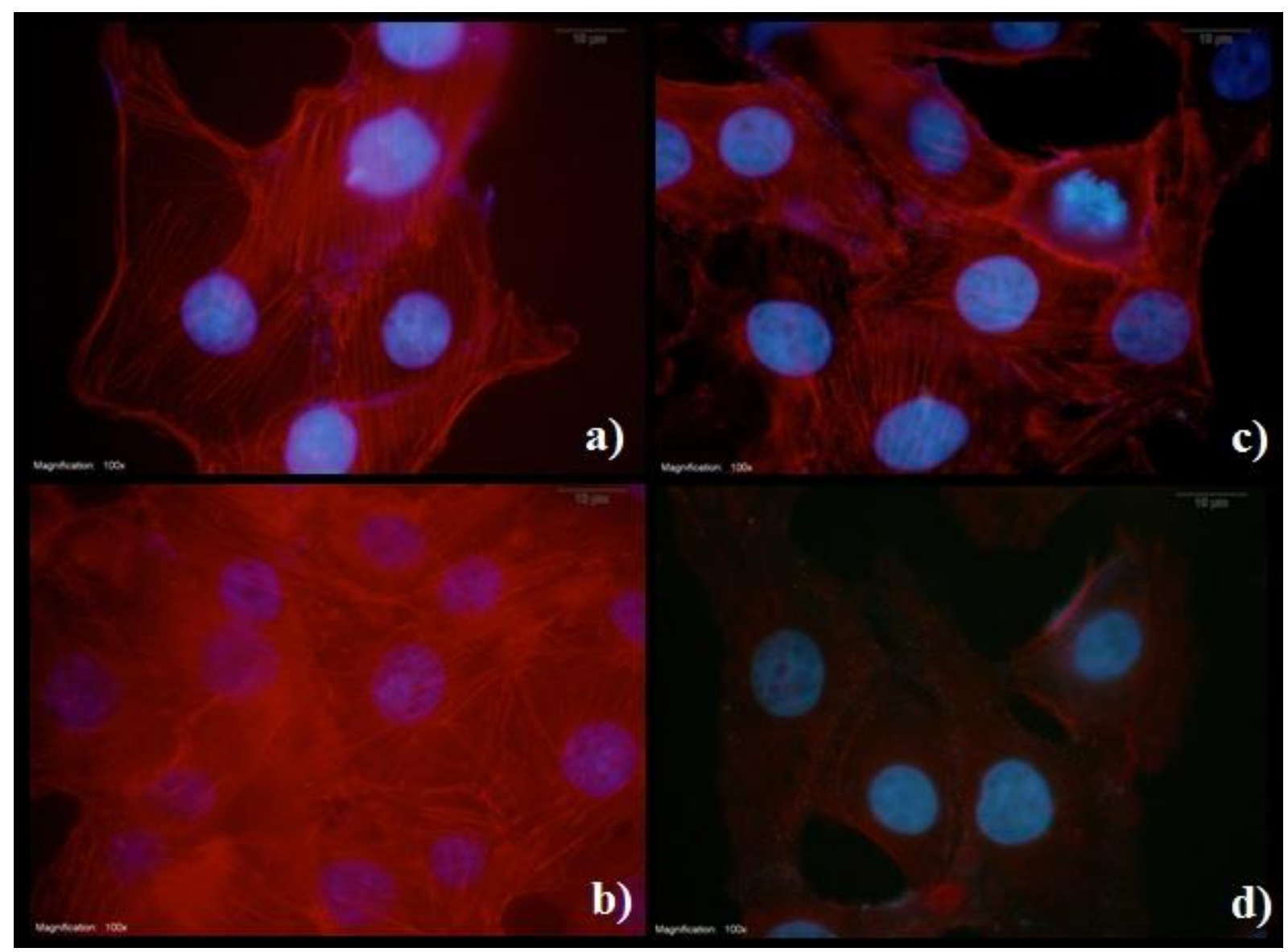

Figure 4. Staining of F-actine by using a Fleurosane microscopy; a) control b)DMSO c) $1 \mu \mathrm{g} \mathrm{ml} l^{-1}$ d) $125 \mu \mathrm{g} \mathrm{m} l^{-1}$.

\section{DISCUSSION}

Because of their potential anti-cancer activities, lichens have an increasing importance for many years [11]. Studies conducted on lichens showed that they have important anti-cancer activities [4]. In most of the anti-cancer studies with lichens, MTT cell viability method was as first method of choice to determine the anti-cancer activities of lichen extracts on cancer cells. In our study, $E$. prunastri $\mathrm{MeOH}$ extracts were found to have antiproliferative activities especially in high doses. In consistent with our findings, anti-proliferative activities of $E$. prunastri on cancer cells were previously reported. E. prunastri $\mathrm{MeOH}$ were reported to have anti-proliferative activities on murine myeloma cells (P3X63-Ag8.653) [13]. In another study, inhibitory effects of acetone extract of E. prunastri was observed in human myeloma (FemX) and colon cancer cells (LS174) and IC50 dose was determined to be $120 \mu \mathrm{g} \mathrm{ml}^{-1}$ for both cells [11]. It was also reported that the $E$ prunastri $\mathrm{MeOH}$ extract inhibits the proliferation of HCT-116 colon cancer cells in a dose- 
dependent manner [12]. While these studies are very important for pre-evaluation, antiproliferative assays do not fully show the anticancer activity of an extract or a compound. Therefore, assessing the apoptosis should be taken into consideration because it is an important sign of anti-cancer activities. Accordingly, in our study, the relationship of the E. prunastri extract with the apoptotic pathway was investigated after assessing anti-proliferative activities.

As we all know apoptosis is a programmed cell death as it is activated in normal circumstances as well as in the elimination of damaged cells [14]. One of the most commonly used method for determining apoptosis in cells is the staining of cells with ANNEXIN V/PI and the analysis in flow cytometry. Phosphatidyl serine is normally found in the cytosolic part of the cell membrane and if the cell undergoes apoptosis, the phosphatidyl serine migrates out of the cell membrane [15]. Annexin $\mathrm{V}$ stains the phosphatidyl serine outside the cell and early or late stages of apoptosis can be measured in this way. Furthermore, it has been determined that some metabolites obtained from lichens induce apoptosis in human cancer cells showing significant anticancer activities. It was also reported that metabolites such as sphaerophorin and pannarin induce apoptosis in melanoma cells [16]. Also, metabolites of E. prunastri were shown to be involved in the cellular cytotoxicity and induction of apoptosis. Moreover, studies on A431 human squamous and malignant mesothelioma cell lines were shown that seconder metabolite of $E$. prunastri, evernic acid, has a low cytotoxic effect [17]. The effects of some lichen metabolites such as parietin, atranorin, usnic acid and gyrophoric acid was also reported on A2780, HeLa, MCF-7, SK-BR-3, HT-29, HCT-116 p53 $3^{+/+}$, HCT-116 p53 ${ }^{-/-}$, HL-60 and Jurkat cells [18]. Results showed that ursinic acid and atronorin shows cytotoxic effect by inducing apoptosis. In our study, MCF7 cells were exposed to E. prunastri extract for 24 and 48 hours, and after the flow cytometric measurements, the extracts were found to be not inducing apoptosis.
Indicating that $\mathrm{MeOH}$ extracts of E. prunastri seems to have no apoptotic activity in MCF7 cells. Apoptosis is evaluated in three pathways: intrinsic, extrinsic, and perforin / granzyme. In all three pathways, Casp 3 is important in that it activates apoptotic reactions [14]. Among these pathways, in the intrinsic pathway anti-apoptotic BCL2 protein which is found in the mitochondria membrane loses the competition against proapoptotic proteins and this led to the release of Cytochrome C and apoptosome is activated [14]. This leads to the activation of the apoptotic pathway involving the activation of Casp 3. To assess the role of intrinsic pathway, we also determined the protein expressions of $\mathrm{p} 53, \mathrm{Bcl} 2$ and Casp3 proteins in our study. As a result of extract treatments, there was no significant decrease or increase in protein expressions of apoptotic pathway proteins. Based on these results, it was determined that E. prunastri $\mathrm{MeOH}$ extract was not effective on the expression of BcL2 and Casp 3 enzymes which are effective in apoptotic pathway.

Casp 3 plays a role in the rearrangement of the cell skeleton and in the cleavage of cells into apoptotic bodies. One of the substrates of Casp 3, the actin-binding protein, gensolin directs actin polymerization. Casp 3 disrupts the gensolin chain and disrupts the cell skeleton during apoptosis [19]. In our study, there was no reduction in density of actin filaments as a result of fluorescent phallodin staining after extract application in MCF7 cells. As a result, there is no increase in Casp 3 protein expression, so that gensolin may not be affected and there is no change in cytoskeletal pattern associated with it.

In conclusion, E. prunastri $\mathrm{MeOH}$ extract has antiproliferative effects on MCF7 cells, yet this effect was not related to the apoptotic pathway as determined by different methodologies. One of the limitations of our study is use of crude extract without any sub-fragmentation of the $\mathrm{MeOH}$ extract. Also, another limitation is the use of one cell line belonging to one type of cancer. It may have different activites on different types of cancers. Considering the antiproliferative effects 
of different extracts of E. prunastri in different cancer cells in previous studies, different breast cancer cells as well as other types of cancer cells and different extracts are should be used in future studies. For more detailed studies, active compounds should also be isolated.

Acknowledgements: This work was supported by the Scientific Research Projects Management Unit of Adiyaman University under Grant (TIPFBAP/2014-0001).

Conflicts of interest: The authors stated that did not have conflict of interests

\section{REFERENCES}

[1]. R.L. Siegel, K.D. Miller, A. Jemal. Cancer statistics. Cancer J Clin. 1986, 65: 5-29.

[2]. American Cancer Society, 2016. Breast Cancer Facts \& Figures 2015-2016. Atlanta: American Cancer Society, Inc. Avaliable at: https://www.cancer.org/content/dam/cancer -org/research/cancer-facts-and statistics/breast-cancer-facts-andfigures/breast-cancer-facts-and-figures2015-2016.pdf.

[3]. M.J. Bak, S.D. Gupta, J. Wahler, N. Suh. Role of dietary bioactive natural products in estrogen receptor-positive breast cancer. Semin Cancer Biol. 2016,41,170-191.

[4]. G. Shrestha, L.L. St Clair. Lichens: a promising source of antibiotic and anticancer drugs. Phytochem Rev. 2013, 12, 229-244.

[5]. K.O. Vartia, Antibiotics in lichens. In: Ahmadjian V, Hale ME (ed.), The Lichens, New York, Academic Press, 1973, pp. 547561

[6]. V. Shukla, G.P. Joshi, M.S.M. Rawat. Lichens as a potential natural source of bioactive compounds: a review. Phytochem Rev. 2010, 9, 303-314.

[7]. V. Cardile, A.C.E.Graziano, R. Avola, M. Piovano, A. Russo. Potential anticancer activity of lichen secondary metabolite physodic acid. Chem Biol Interact. 2017, 263, 36-45.
[8]. M. Bessadottir, E.A. Skuladottir, S. Gowan, S. Eccles, S. Omarsdottir, H.M. Ogmundsdottir. Effects of anti-proliferative lichen metabolite, protolichesterinic acid on fatty acid synthase, cell signalling and drug response in breast cancer cells Phytomedicine. 2014, 21, 1717-1724.

[9]. Russo, S. Caggia, M. Piovano, J. Garbarino, V. Cardile. Effect of vicanicin and protolichesterinic acid on human prostate cancer cells: role of Hsp70 pro- tein. Chem Biol Interact. 2012, 195, 1-10 .

[10]. M. Backorova, R. Jendzelovsky, M. Kello, M. Backor, J. Mikes, P. Fedorocko. Lichen secondary metabolites are responsible for induction of apoptosis in HT-29 and A2780 human cancer cell lines Toxicol in Vitro. 2012, 26, 462-468.

[11]. M. Kosanic, N. Manojlovic, S. Jankovic, T. Stanojkovic, B. Rankovic. Evernia prunastri and Pseudoevernia

furfuraceae lichens and their major metabolites as antioxidant, antimicrobial and anticancer agents. Food Chem Toxicol. 2013, 53, 112-118.

[12]. T. Mitrovic, S. Stamenkovic, V. Cvetkovic, S.Tosic, M. Stankovic, I. Radojevic, O. Stefanovic, L. Comic, D. Dacic, M. Curcic, S. Markovic. Antioxidant, Antimicrobial and Antiproliferative Activities of Five Lichen Species. Int. J Mol Sci. 2011, 12, 5428-5448.

[13]. D. Triggiani, D. Ceccarelli, A. Tiezzi, T. Pisani, S. Munzi, C. Gaggi, S. Loppi. Antiproliferative activity of lichen extracts on murine myeloma cells. Biologia. 2009, 64, 59-62.

[14]. S. Elmore. Apoptosis: A review of programmed cell death. Toxicol. Pathol. 2007, 35, 495-516.

[15]. Vermes, C. Haanen, H. Steffens-Nakken, C. Reutellingsperger. A novel assay for apoptosis flow cytometric detection of phosphatidylserine expression on early apoptotic cells using fluorescein labelled annexin V. J Immunol Methods. 1995, 184, $39-51$. 
[16]. B. Burlando, E. Ranzato, A. Volante, G. Appendino, F. Pollastro, L. Verotta. Antiproliferative effects on tumour cells and promotion of keratinocyte wound healing by different lichen compounds. Planta medica. 2009, 75, 607613.

[17]. Russo, M. Piovano, L. Lombardo, J. Garbarino, V. Cardile. Lichen metabolites prevent UV light and nitric oxide-mediated plasmid DNA damage and induce apoptosis in human melanoma cells. Life Sci. 2008, $83,468-474$.
[18]. M. Backorova, M. Backor, J. Mikes, R. Jendzelovski, P. Fedorocko. Variable responses of different human cancer cells to the lichen compounds parietin, atranorin, usnic acid and gyrophoric acid Toxicol in Vitro, 2011, 25, 37-44.

[19]. S. Kothakota, T. Azuma, C. Reinhard, A. Klippel, J. Tang, K. Chu, T.J. McGarry, M.W. Kirschner, K. Koths, D.J. Kwiatkowski, L.T. Williams (1997). Caspase-3-generated fragment of gelsolin: effector of morphological change in apoptosis. Science. 1997, 278, 294-298. 